\title{
CYPS MOLECULAR BIOMARKERS IN RAINBOW TROUT Oncorhynchus mykiss TO ASSESS OIL CONTAMINATION IN A PATAGONIAN STREAM
}

\author{
Leonardo Ramón LEGGIERI ${ }^{1 *}$, Julieta Soledad DE ANNA ${ }^{1}$, Gerardo Abel CERÓN ${ }^{2}$, \\ Luis ARIAS DARRAZ ${ }^{3}$, Daniela FUENTES MONASTERIO ${ }^{3}$, Juan Guillermo CÁRCAMO ${ }^{4}$ and \\ Carlos Marcelo LUQUET ${ }^{1}$
}

${ }^{1}$ Laboratorio de Ecotoxicología Acuática, Instituto de Investigaciones en Biodiversidad y Medioambiente, Consejo Nacional de Investigaciones Científicas y Técnicas. Ruta 61, kilómetro 3, CCP7, Junín de los Andes, Neuquén, Argentina, C. P. 8371

${ }^{2}$ Laboratorio de Zoología, Centro Regional Universitario Bariloche, Universidad Nacional del Comahue, Consejo Nacional de Investigaciones Científicas y Técnicas. Quintral 1250, San Carlos de Bariloche, Río Negro, Argentina, C. P. 8400

${ }^{3}$ Facultad de Ciencias, Instituto de Bioquímica y Microbiología, Universidad Austral de Chile,Campus Isla Teja. Casilla 567, Valdivia, Chile

${ }^{4}$ Fondo de Financiamiento de Centros de Investigación en Áreas Prioritarias, Interdisciplinary Center for Aquaculture Research - Facultad de Ciencias, Instituto de Bioquímica y Microbiología, Universidad Austral de Chile, Campus Isla Teja, Casilla 567, Valdivia, Chile

*Corresponding author: lrleggieri@gmail.com

(Received August 2016; accepted February 2017)

Key words: CYP450, petroleum spill, fish, contaminated stream, Patagonia

\begin{abstract}
Cytochrome P450 (CYP) gene expressions were studied by semi-quantitative polymerase chain reaction (PCR) to assess oil pollution using liver and gills of juvenile rainbow trout Oncorhynchus mykiss sampled from La Mina stream (Bariloche, Argentina), up and downstream of a discharge of petroleum spill from an unproductive wellbore. Data was complemented with laboratory exposure to water accommodated fraction (WAF) from the oil spill. Oil exposure induced gill and liver CYP1A transcription (1.21.4-fold), which was used as reference biomarker. In both organs, CYP2K1 transcript was induced after $5 \%$ WAF exposure, $24 \mathrm{~h}$ (1.8-2.0-fold), and it was down-regulated in more extended time (1.2-1.5-fold). CYP2M1 transcript levels were down-regulated in liver of impacted wild trout and in trout exposed to $5 \%$ WAF during $96 \mathrm{~h} \mathrm{(1.5-}$ 1.7-fold). CYP2K1 and CYP2M1 are involved in the metabolism of fatty acids and estrogenic hormones, and its down-regulation would indicate metabolic alterations. CYP3A27 levels were only induced in liver of wild trout (1.6-fold), possibly related to crosstalk between aryl hydrocarbon receptor and pregnane $\mathrm{X}$ receptor signaling pathway. While CYP1A mRNA expression appears to be a more robust biomarker for detecting the effects of crude oil under different dose and exposure time, the expression of CYP2K1, CYP2M1 and CYP3A27 mRNAs would indicate different time exposure to oil pollution, particularly under high oil concentration in water. Hence, patterns of multiple CYP genes expression in rainbow trout gills and liver could be especially valuable for monitoring programs of crude oil pollution and remediation actions on Patagonian freshwater ecosystems.
\end{abstract}


Palabras clave: CYP450, derrame de petróleo, peces, arroyo contaminado, Patagonia

\title{
RESUMEN
}

\begin{abstract}
Se estudió la expresión génica de citocromos P450 (CYP) mediante reacción semicuantitativa en cadena de la polimerasa (PCR, por sus siglas en inglés), en muestras de hígado y branquias de trucha arcoíris Oncorhynchus mykiss juveniles capturadas en un arroyo que es afectado por un derrame de petróleo. El estudio se completó con exposiciones in vivo a la fracción soluble del petróleo del vertedero (WAF). El CYP1A, usado como biomarcador de referencia, fue inducido por el petróleo (1.2-1.4-veces) en branquias e hígado. En ambos órganos, el CYP2K1 fue inducido después de 24 h con $5 \%$ WAF (1.8-2.0-veces), y subregulado en tiempos más extensos (1.2-1.5-veces). CYP2M1 fue subregulado en el hígado de truchas contaminadas y de aquellas expuestas a $96 \mathrm{~h}$ con $5 \%$ (1.5-1.7-veces). Dado que CYP2K1 y CYP2M1 participan del metabolismo de ácidos grasos y de hormonas estrogénicas, la subregulación indicaría alteraciones en estos metabolismos. CYP3A27 fue inducido sólo en el hígado de las truchas silvestres afectadas por petróleo, posiblemente por efectos cruzados entre las señalizaciones de los receptores de hidrocarburos de arilo y X de pregnano. Mientras que la expresión de CYP1A mRNA pareciera ser un biomarcador más robusto para detectar los efectos del petróleo crudo bajo diferentes dosis y tiempos de exposición, las expresiones de CYP2K1, CYP2M1 y CYP3 mRNAs permitirían identificar distintos tiempos de exposición a la contaminación por petróleo, particularmente cuando las concentraciones de crudo sean altas. Así, los patrones múltiples de expresión de los genes CYP en branquias e hígado de las trucha arcoíris podrían ser útiles en programas de monitoreo y remediación de contaminaciones de petróleo en ecosistemas acuáticos de Patagonia.
\end{abstract}

\section{INTRODUCTION}

Oil exploration, exploitation, and storage are key economic activities in Patagonia, which have occasionally produced oil pollution events (SAyDS 2000, Barquín et al. 2011). The advance of these activities can endanger Patagonian aquatic ecosystems, which are very well preserved until now. However, in the early 20th century, the black gold fever had already impacted some Patagonian environments in several ways, such as the footprint of old unproductive wellbores. One of these old wellbores is located near to Bariloche city, North West Patagonia, and was under production from 1900 up to the 1940s, when it was dismantled leaving a permanent heavy oil spill (Mancini and Serna 1989). This spill runs into La Mina stream, a low order stream located in a steppeforest transition area in the sub-Andean Mountains within the Nirihuau river system that drains into the Nahuel Huapi Lake (Mancini and Serna 1989, Cazau et al. 2005), a glacial lake, with great touristic and conservation value (Fig. 1). Considering the public concern about adverse health effects of persistent oil pollution on highly valued aquatic ecosystems, particularly on water and edible fish, it is necessary to develop tools to assess the impact of this oil spill.
Fish have proved to be useful models when it comes to evaluating the health of aquatic ecosystems. Rainbow trout Oncorhynchus mykiss is a useful model for toxicology studies because of its sensitivity to chemicals (Bailey et al. 1996, Buhler and Wang-Buhler 1998) and because it has been introduced in water courses around the world and is particularly abundant in Patagonia (Quirós 1990, Pascual et al. 2002), including La Mina stream. Since direct measurement of tissue hydrocarbon concentrations generally does not provide a useful indicator of petroleum exposure in fish and could be expensive (Collier et al. 1996), we focused on the transcription of genes possibly involved in aromatic hydrocarbons metabolism, in order to find sensitive biomarkers of oil exposure. The phase I xenobiotic metabolizing enzymes are represented mainly by cytochrome P450 (CYP) multi-enzymatic complex, that catalyzes hydrolysis, oxidation and reduction reactions, by adding or exposing functional groups (Danielson 2002). Seven CYP families have been reported for the rainbow trout (Uno et al. 2012).

CYP1A mRNA expression is induced by minuscule amounts of diverse aromatic compounds through the aryl hydrocarbon receptor (AhR) signaling pathway, being a sensitive biomarker of exposure 

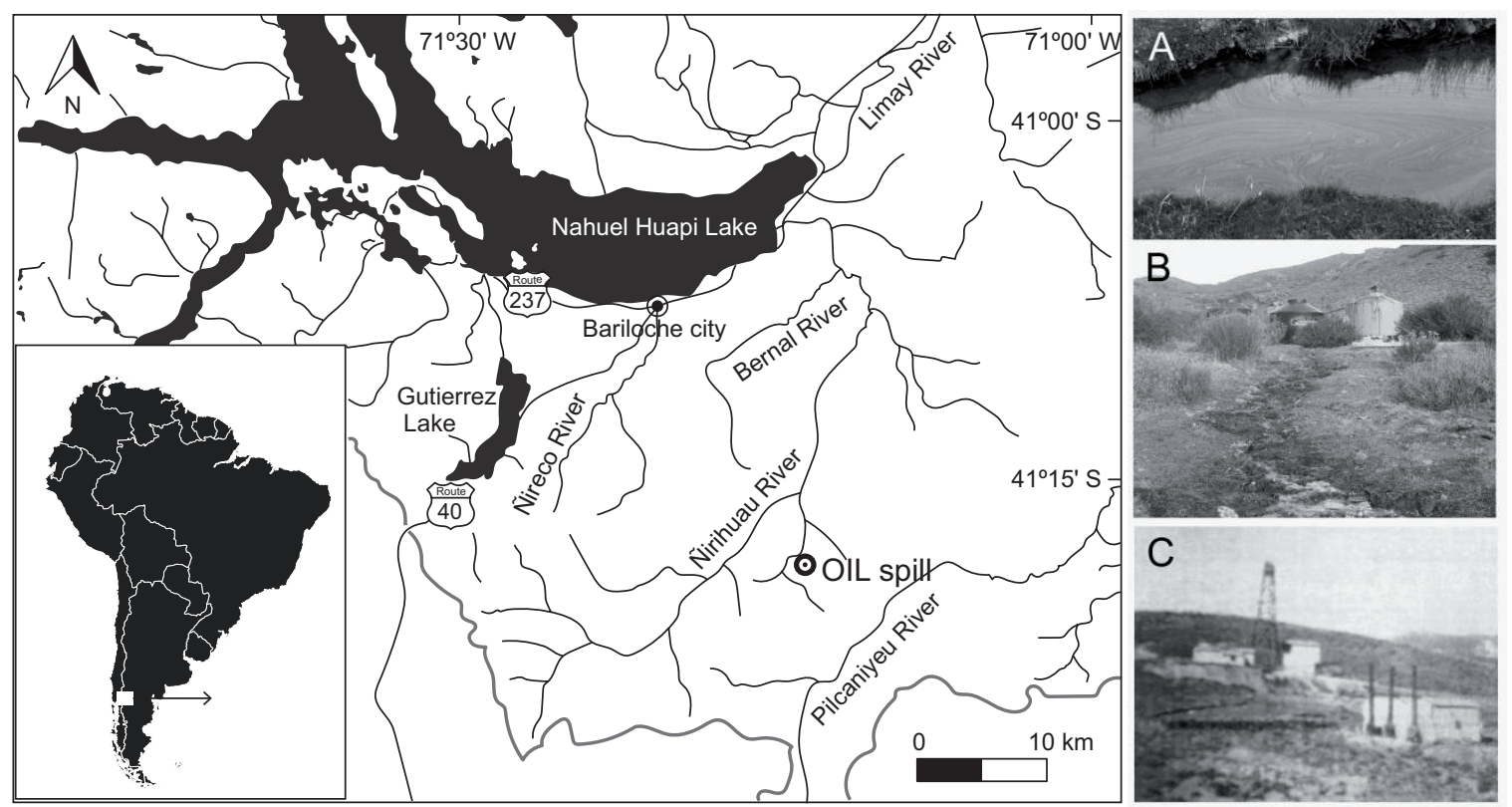

Fig. 1. Location of the study site in La Mina stream, a tributary of Nirihuau river, $30 \mathrm{~km}$ from Bariloche City. (A) Oil remains afloat on the surface of stream water. (B) Oil spill sources running towards the stream. (C) Oil extraction well next to the stream in the 30s (photograph by Pedro Penna, Parsons 2002)

to aromatic hydrocarbon contaminants (Uno et al. 2012). Hence, CYP1A transcript expression serves as reference in biomarkers of crude oil pollution. The CYP2 family of enzymes is represented by CYP2K1 and CYP2M1 in rainbow trout (Buhler et al. 1994, Yang et al. 1998). CYP2K1 is the most abundant constitutively expressed hepatic cytochrome P450 found in sexually immature rainbow trout and it shows an unusually high sensitivity to carcinogens (Bailey et al. 1996). CYP2K1 has benzphetamine N-demethylase and steroid hydroxylase activities, and both CYP2K1 and CYP2M1 are involved in lauric acid metabolism and some longer fatty acids in rainbow trout (Yang et al. 1998, 2000) and both are involved in the metabolism of estrogenic hormones (Buhler and Wang-Buhler 1998, Buhler et al. 2000). A tropical reef fish exposed to oily water showed an induction of CYP2K1 and CYP2M1 proteins (Zhu et al. 2008). Thus, anomalous expression of both CYP2 could impact on steroid and fatty acid homeostasis in rainbow trout (e.g. Buhler et al. 2000). The CYP3 family of enzymes is represented by CYP3A27 and CYP3A45 in rainbow trout, being both involved in steroid hormone metabolism (Lee et al. 2001, Lee and Buhler 2003). The mRNA of CYP3A27 is $55 \%$ identical to human CYP3A4, and their encoded proteins (LMC5-like) have structural and functional similarities (Miranda et al. 1991). Through pregnane X receptor (PXR) signaling pathway, some polycyclic aromatic hydrocarbons induce human CYP3A4 (Luckert et al. 2013). Similarly, aromatic hydrocarbons could act as endocrine-disrupting chemicals in O. mykiss by inducing CYP3A27 mRNA expression, possibly affecting fish reproduction. The CYP3A27 induction could provide a useful biomarker for the environmental monitoring. Consequently, since several CYPs could be influenced by exposure to polycyclic aromatic hydrocarbons, oil contamination could affect biosynthesis and metabolism of many important endogenous constituents of rainbow trout.

In this study we analyzed the suitability of different possible CYPs molecular biomarkers in $O$. mykiss for detection of oil contamination. We focused on gill and liver tissues because the gills are the primary route of hydrocarbon uptake from water, and the liver is the main organ for metabolism of toxic oil constituents (Thomas and Rice 1981). In these organs, we assessed the effects of petroleum on the transcriptional expression of CYP1A, CYP2K1, CYP2M1 and CYP3A27. Our aim was to assess the use of mRNAs levels, by semiquantitative reverse transcription polymerase chain reaction (RT-PCR), of these CYP forms in rainbow trout gill and liver. First, we explored the heavy crude oil effects on these possible biomarkers in wild juvenile rainbow trout that were caught in the La Mina stream, up and downstream of the oil spill. Second, we investigated the effects of the water-accommodated fractions 
(WAF) from La Mina's oil, through laboratory experiments, on these possible biomarkers in juvenile rainbow trout.

\section{MATERIALS AND METHODS}

\section{Study area}

There are four oil spills located at 5-20 m from the water's edge, covering an area of $400 \mathrm{~m}^{2}$. The spills converge into a unique source point of pollution, with 2-4 liters of crude oil per day entering the stream (in February 2015). The spills are the relict of a wellbore, an attempt to have oil production during the early 20th century and then abandoned (Mancini and Serna 1989). The oil sampled from surface seepage was characterized as immature heavy crude petroleum $(\mathrm{Ro}=0.44-0.53 \%$, American Petroleum Institute degree $(\mathrm{API})=18^{\circ}$ and sulfur $=0.45 \%$; Cazau et al. 2005), composed by $33.7 \%$ saturated, $17.8 \%$ aromatics, $5.9 \%$ asphaltenes and $42.6 \%$ NSOs (compounds with nitrogen, sulfur, oxygen and heavy metals; data provided by YPF S.A. Argentina).

The study was conducted in two 300 -m-long reaches: upstream-control $\left(41^{\circ} 17^{\prime} 34^{\prime \prime} \mathrm{S}-71^{\circ} 11^{\prime} 14^{\prime \prime}\right.$ $\mathrm{W}, 1011$ masl) and downstream-impacted $\left(41^{\circ} 17^{\prime} 21^{\prime \prime}\right.$ $\mathrm{S}-71^{\circ} 10^{\prime} 58^{\prime}$ W, $1001 \mathrm{masl}$ ) of the oil spill during summer (dry season), 1-2 February 2015. The riparian vegetation of the reaches is well preserved, with dominance of shrubby plants and the herbaceous Festuca gracillima. The upstream reach is up of a 1.4 $\mathrm{m}$ high waterfall, $50 \mathrm{~m}$ upstream from the spill. This impairs juvenile fish migrate from the downstream to the upstream reach, but it might not necessarily prevent migration from the upstream to the downstream reach. The stream bottom is composed of boulder cobble substrates and the stream channel has alternated riffle-pool habitats. The climate is cold-temperate, with a mean annual temperature of $8.7^{\circ} \mathrm{C}$ and annual precipitations of $850 \mathrm{~mm}$. During the study, the stream reaches were characterized by mean water velocity of $0.31 \pm 0.11 \mathrm{~m} / \mathrm{s}$, discharge of $78 \pm 12 \mathrm{~L} / \mathrm{s}$, mean width of $0.75 \pm 0.48 \mathrm{~m}$, mean depth of $0.35 \pm 0.31 \mathrm{~m}$, water temperature $16-19^{\circ} \mathrm{C}$, conductivity $80 \pm 27 \mu \mathrm{S} / \mathrm{cm}$ and $\mathrm{pH} 6.8 \pm 0.2$. Fish are represented by a single species, the exotic rainbow trout $O$. mykiss.

\section{Total petroleum hydrocarbons (TPH)}

Triplicate samples were collected at the upstream reach $(-200,-250$ and $-350 \mathrm{~m})$, at the oil spill (zero meters), at the downstream reach $(50,100$ and $200 \mathrm{~m})$ and further downstream $(400,800$ and $1600 \mathrm{~m})$.
Water samples were collected in polyethylene bottles and filtered through glass-fiber filters: pore size $=$ $0.7 \mu \mathrm{m}$; Whatman GF/F, Maidstone, UK. Sediment samples were collected with a core sampler $(4 \mathrm{~cm}$ diameter, $3 \mathrm{~cm}$ depth), from stream pools and stored in polyethylene flasks at $4{ }^{\circ} \mathrm{C}$ in the dark. The TPH were estimated in the WAF solution, and in stream water and sediment samples. The WAF was prepared according to Singer et al. (2000) using $4.75 \mathrm{~g}$ of crude petroleum from the spill per L of stream water. Each sample was acidified with $\mathrm{HCl}$ to a $\mathrm{pH}<2$. The TPH was extracted from each with carbon tetrachloride and was estimated by the analysis of the triple peak method (EPA 1978) at three spectral regions: 2930 $\mathrm{cm}^{-1}\left(-\mathrm{CH}_{2}\right), 2960 \mathrm{~cm}^{-1}\left(-\mathrm{CH}_{3}\right)$ and $3030 \mathrm{~cm}^{-1}$ (Ar$\mathrm{CH}$ ), using a Fourier transform infrared (FT-IR) spectrometer (Thermo Scientific ${ }^{\mathrm{TM}}$; detection limit $=$ $0.04 \mathrm{mg} / \mathrm{L})$. The procedure was replicated twice for each sample, with an intra-deviation $<10 \%$.

\section{Fish samples and treatments}

Wild, juvenile rainbow trout $(10.7 \pm 6.1 \mathrm{~g}, 101$ $\pm 23 \mathrm{~mm}, \mathrm{n}=24,12$ individuals per reach) of both sexes were caught by net casting. Fish were killed by a blow to the head. Liver and gills from four fish were aseptically dissected out and pooled into one sample of each organ, obtaining a total of three pooled samples per organ and per reach. For the experiments, juvenile rainbow trout $(3.9 \pm 0.8 \mathrm{~g}, 75 \pm 5 \mathrm{~mm})$ were obtained from the Centro de Ecología Aplicada de Neuquén (CEAN) hatchery (Neuquén, Argentina) and acclimatized for 2 days before exposure. Fish were kept in $1.5 \mathrm{~L}$ glass fishbowls (4 fish per fishbowl, $\sim 10 \mathrm{~g}$ fish/L) with continuously aerated fresh water from Chimehuin river, at a temperature of $16-18^{\circ} \mathrm{C}$ and $\mathrm{pH}$ 7.4-7.6 (12 h light-12 $\mathrm{h}$ dark photoperiod). Treatments consisted in $24 \mathrm{~h}$ and $96 \mathrm{~h}$ exposure to $1 \%$ and $5 \%$ WAF, by sextuplicate, with the respective controls. Fish were killed and dissected as described above for field samples. Field and laboratory samples for mRNA expression analysis were stored in RNA-later ${ }^{\circledR}$ (Life technologies) at $-20{ }^{\circ} \mathrm{C}$.

\section{CYPs transcriptional expression}

Total RNA was extracted from 80 - $120 \mathrm{mg}$ of each sample using TRIzol ${ }^{\circledR}$ reagent according to manufacturer's instructions. RNA concentration was measured at $260 \mathrm{~nm}$ and quality was examined by $260 / 230$ and 260/280 ratios. Samples were diluted with ultra-pure water to adjust to a concentration of $2.0 \mu \mathrm{g} / \mu \mathrm{L}$ and stored at $-80^{\circ} \mathrm{C}$. The synthesis of cDNA was performed with Moloney Murine Leukemia Virus (M-MLV) Reverse Transcriptase kit 
TABLE I. SPECIFIC PRIMERS FOR REVERSE TRANSCRIPTION POLYMERASE CHAIN REACTION (RT-PCR) USED IN THIS STUDY

\begin{tabular}{|c|c|c|c|c|c|}
\hline \multirow{2}{*}{$\begin{array}{l}\text { Target } \\
\text { gene }\end{array}$} & \multicolumn{2}{|c|}{ Primer sequence $\left(5^{\prime}->3^{\prime}\right)$} & \multirow{2}{*}{$\begin{array}{l}\text { Amplicon } \\
\text { size (bp) }\end{array}$} & \multirow{2}{*}{$\begin{array}{l}\text { Annealing } \\
\text { temp }\left({ }^{\circ} \mathrm{C}\right)\end{array}$} & \multirow{2}{*}{$\begin{array}{c}\text { GenBank } \\
\text { accession no. }\end{array}$} \\
\hline & Fordward & Reverse & & & \\
\hline CYP1A & agtgctgatggcacagaactcaa & agctgacagcgcttgtgctt & 218 & 60 & AF015660.1 \\
\hline CYP2K1 & ctcacaccaccagccgagat & cttgacaaatcctccetgctcat & 164 & 55 & AF0455053 \\
\hline CYP2M1 & gctgtatatcacactcacctgctttg & cccctaagtgetttgcatgtatagat & 194 & 55 & OMU16657 \\
\hline CYP3A27 & tctgctgatgcccaaacga & cgttgttggactcttcagagtggta & 110 & 55 & OMU96077 \\
\hline$\beta$-actin & gccgggttcgctggagatga & gcgtgggcagagcgtacc & 466 & $55-60$ & ВТ047241 \\
\hline
\end{tabular}

(Invitrogen). Duplex PCR reactions were performed with the GoTaq ${ }^{\circledR}$ Green Master Mix kit (Promega), in a Swift Maxi Gradient Thermal Cycler, as follows: $94{ }^{\circ} \mathrm{C}$ for $3 \mathrm{~min}, 27$ cycles at $94{ }^{\circ} \mathrm{C}$ for $30 \mathrm{~s}$ (denaturation), $55-64{ }^{\circ} \mathrm{C}$ for $30 \mathrm{~s}$ (annealing) and $72{ }^{\circ} \mathrm{C}$ for $30 \mathrm{~s}$ (DNA chain extension) with a final extension at $72{ }^{\circ} \mathrm{C}$ for $10 \mathrm{~min}$. The number of cycles of denaturation phase was selected to catch the exponential amplification, by previous calibration of each mRNA. The annealing temperatures and primer pairs used during the duplex PCR for each gene are shown in Table I. The amplified products were separated by $2 \%$ agarose gel electrophoresis for $50 \mathrm{~min}$ at $90 \mathrm{~V}$ in TAE $1 \mathrm{x}(0.04 \mathrm{M}$ Tris, 0.0001 M EDTA, pH 8.0) buffer, visualized using SYBR ${ }^{\circledR}$ Safe DNA gel stain (Invitrogen), and photographed under UV light. Bands were analyzed densitometrically using Image J software. A 100 bp ladder (Winkler) was used as the molecular mass marker. The presence of a single product of the appropriate size, identical to the reference experiments, was considered as a positive result. $\beta$-actin was used as housekeeping gene and loading control. The relative expression of each gene was calculated as the ratio gene/ $\beta$-actin.

\section{Data analysis}

All statistical analyzes were performed using SPSS 11.5 (Inc., Chicago, Illinois, USA), under the license from Universidad Nacional de Luján, Argentina. All data are expressed as the mean \pm standard deviation (n). The mRNA expression (gene/ $\beta$-actin) data from field samples were analyzed by Student's T-test, and data from the laboratory experiment were analyzed by two-way ANOVA. The explanatory variables in the two-way ANOVA were exposure time (24 and $96 \mathrm{~h})$ and WAF concentration $(0,1$ and $5 \%$ ). We performed post hoc comparisons between control and treatments, for both 24 and $96 \mathrm{~h}$, of all pairs of groups using two-sided significance levels with a Bonferroni adjustment.

\section{RESULTS}

\section{Total petroleum hydrocarbons}

The TPH was $5.2 \pm 0.7 \mathrm{mg} / \mathrm{L}$ in the stock solution of WAF, $74.5 \pm 18.1 \mu \mathrm{g} / \mathrm{L}$ in the WAF $1 \%$ solution and $284.4 \pm 75.2 \mu \mathrm{g} / \mathrm{L}$ in the WAF $5 \%$ solution. The TPH concentrations in the stream at the oil spill discharge (zero meters) were $23.2 \pm 8.7 \mu \mathrm{g} / \mathrm{L}$ in water and $1.9 \pm 0.3 \mathrm{mg} / \mathrm{g}$ in sediments of La Mina stream. $\mathrm{TPH}$ concentration in water was $4.5 \pm 15.0 \mu \mathrm{g} / \mathrm{L}$ before the oil spill (upstream, -200 to $-350 \mathrm{~m}$ ), 106.4 $\pm 51.1 \mu \mathrm{g} / \mathrm{L}$ after the oil spill (downstream; 5 to 200 $\mathrm{m}$ ) and $89.3 \pm 78.2 \mu \mathrm{g} / \mathrm{L}$ further downstream (400 to $1600 \mathrm{~m}$ ) of the oil spill; with an increase of 23-fold from up to downstream reach. TPH concentration in sediments was $0.17 \pm 0.20 \mathrm{mg} / \mathrm{g}$ in upstream reach, $3.16 \pm 1.55 \mathrm{mg} / \mathrm{g}$ in downstream reach and $1.26 \pm$ $0.92 \mathrm{mg} / \mathrm{g}$ in further downstream reach.

\section{CYPs transcriptional expression in wild rainbow trout}

The expression levels of CYP1A mRNA were significantly higher in liver and gill (1.34 and 1.24-fold, respectively) of trout from the impacted reach relative to the control trout (from upstream of the spill). The levels of CYP2K1 mRNA were significantly lower in liver and gill (1.54 and 1.46-fold, respectively) in trout from the impacted reach relative to control. In liver, the CYP2M1 mRNA levels were lower (1.47fold) in trout from the impacted reach relative to control; while CYP3A27 mRNA levels were higher (1.58-fold; Fig. 2).

\section{CYPs transcriptional expression in rainbow trout with WAF treatment}

The transcript levels of CYP1A were induced by $24 \mathrm{~h}$ exposure to $1 \%$ and $5 \% \mathrm{WAF}$ in liver and gill (1.2 and 1.4-fold, respectively), and by $96 \mathrm{~h}$ exposure to $5 \%$ WAF in liver (1.4-fold), meaning that gill CYP1A levels returned to control values after $96 \mathrm{~h}$. The transcript levels of CYP2K1 were induced by 


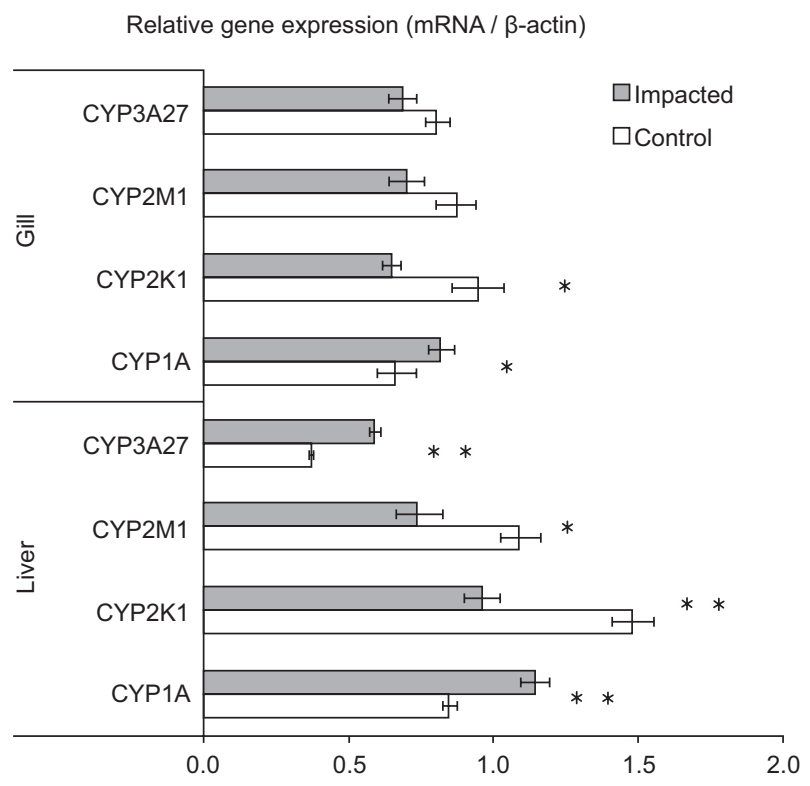

Fig. 2. mRNA expression levels (relative to $\beta$-actin) of CYP327, CYP2M1, CYP2K1 and CYP1A genes in liver and gill of wild rainbow trout Oncorhynchus mykiss from upstream (control) and downstream of the oil spill (impacted) in La Mina stream. Each value is the mean $\pm \mathrm{SD}(\mathrm{n}=3)$. Asterisks indicate differences between upstream and downstream fish $(* \mathrm{p}<0.05$ and $* * \mathrm{p}<0.005$, Student's T-test)

$24 \mathrm{~h}$ exposure to $5 \% \mathrm{WAF}$ in liver and gill (2.0 and 1.8-fold, respectively), but they were down-regulated by $96 \mathrm{~h}$ exposure to $5 \% \mathrm{WAF}$ in liver and gill (1.2 and 2.1-fold, respectively). The transcript levels of CYP2M1 declined 1.8 -fold after $96 \mathrm{~h}$ exposure to $5 \%$ WAF in liver, and the CYP3A27 transcript levels did not show changes after treatments (Fig. 3, Table II). Significant interactions denote different responses to WAF at 24 and $96 \mathrm{~h}$ (Table II). The controls of CYPs levels tended to increase over time, except gill CYP2M1 levels, being a significant source of variability (Fig. 3, Table II).

\section{DISCUSSION}

The rainbow trout Oncorhynchus mykiss is widely distributed around the world and is present in most of the freshwater ecosystems of Patagonia. This, along with the fact that its metabolic pathways related to oil contaminants detoxification are relatively well known, makes this species a good bioindicator (Moore et al. 2004). We assessed the molecular responses to oil pollution in juvenile rainbow trout sampled from La Mina stream, $30 \mathrm{~km}$ from Bariloche City. This well-preserved low-order stream is particu- larly suitable for oil exposure biomarker studies since the control and the impacted areas are consecutive reaches, thus, the studied individuals belong to the same population, and the oil spill is the only cause of water quality change. The field study was combined with laboratory exposure to WAF obtained from the oil source, which affects the same stream. Gene transcript expression of several cytochrome P450 oxidases was studied by semi-quantitative PCR in both field and laboratory.

CYP1A is a hallmark of AhR signaling pathway activation in fish and is a sensitive biomarker of exposure to PAHs and other oil compounds (Varanasi 1989, Jönsson et al. 2006, Clark et al. 2010). Here, as it was to be expected, crude oil exposure induced CYP1A transcription in O. mykiss liver and gill. These clear and consistent changes reaffirm CYP1A transcript expression as a good semiquantitative biomarker for crude oil exposure. The maximum induction of CYP1A transcript expression has been reported to start eight to sixteen hours after exposure (Minura et al. 1999, Nahrgang et al. 2009, Chang et al. 2014) and remained elevated in exposed fish (Jönsson et al. 2010). This explains the similar response in liver CYP1A transcript levels at 24 and $96 \mathrm{~h}$ during our experiments, without dose-dependent effects. In contrast, gill CYP1A transcripts returned to control levels before $96 \mathrm{~h}$. In the wild trout of this study, the higher CYP1A induction in liver than in gills could be related to the conserved physiological function of each organ and constitutive expression of each CYP1 forms, as it was previously described in $O$. mykiss (Jönsson et al. 2010) and other fish (Jönsson et al. 2007, Zanette et al. 2009). Also, the difference between gill and liver CYP1A levels in the experiment and stream samples could be a consequence of AhR pathway down-regulation by, for instance, the induction of the AhR repressor (AHRR), which competes with AhR for the aryl hydrocarbon nuclear translocator (ARNT) heterodimerization (Mimura et al. 1999, Meyer et al. 2003); or by proteolysis of AhR through ubiquitination (Ma and Baldwin 2002). These possible explanations exceed the scope of our research and further studies will be needed to understand gill CYP1A mRNA regulation in rainbow trout.

CYP1A are involved in the detoxification pathway of hydrocarbons, while CYP2K1, CYP2M1 and CYP3A27 are involved in other metabolisms. Hence, the response of the last ones to crude oil could be less specific but not less useful indicating some metabolic alterations. The transcription of CYP2s and CYP3 are affected by foreign compounds as 
(A)
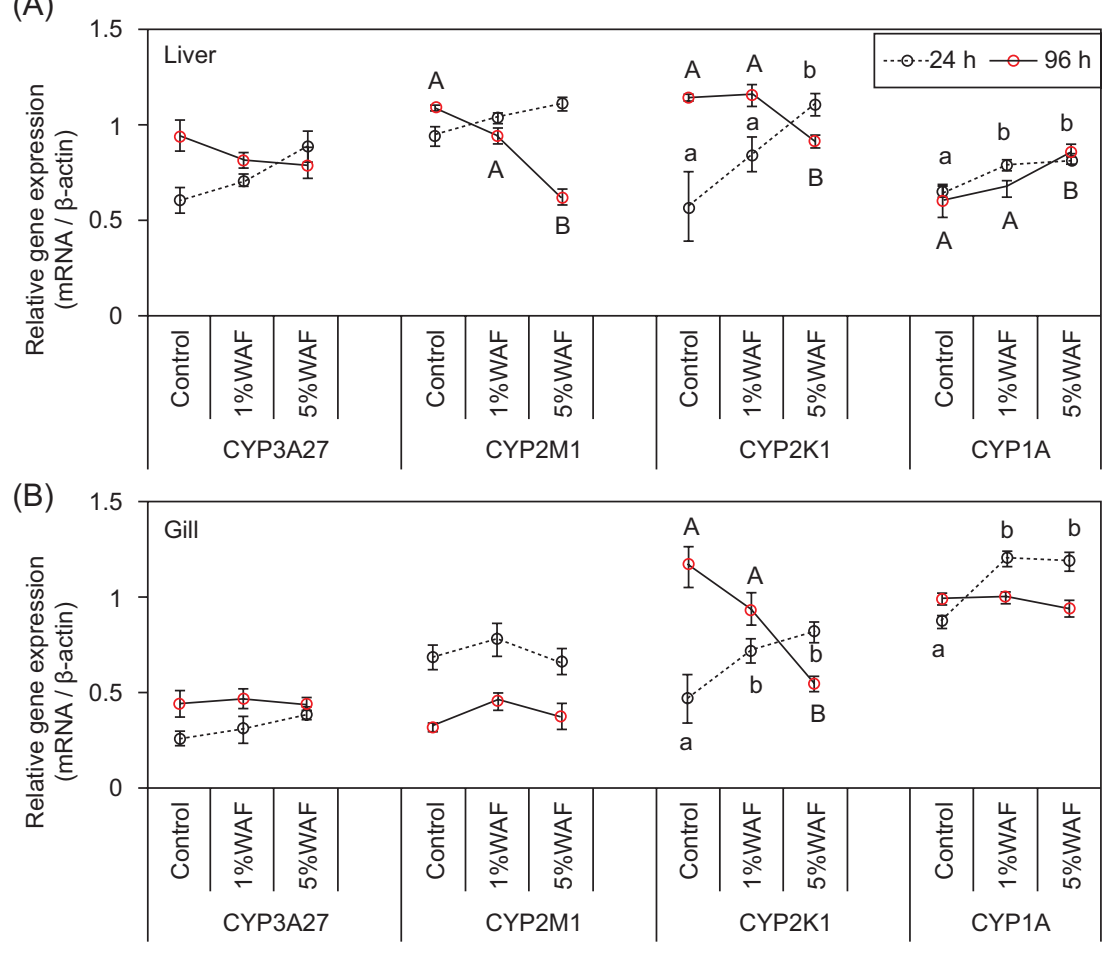

Fig. 3. mRNA expression levels (relative to $\beta$-actin) of CYP327, CYP2M1, CYP2M1 and CYP1A genes in liver (A) and gill (B) of rainbow trout Oncorhynchus mykiss after 24 hours (dotted line) and 96 hours (solid line) of exposure to $1 \% \mathrm{WAF}$ and $5 \%$ WAF (WAF: water accommodated fraction prepared from the crude oil obtained in La Mina spill). Values are mean $\pm \operatorname{SD}(n=6)$. Letters denote significant differences among treatments within each time, $24 \mathrm{~h}$ (lowercase letters) and $96 \mathrm{~h}$ (capital letters) from Bonferroni test (Table II)

TABLE II. RESULTS OF TWO-WAY ANOVAS FROM TROUT CYPS TRANSCRIPTS AFTER CRUDE OIL WATER ACCOMMODATED FRACTION (WAF) TREATMENT FOR LIVER AND GILL. TABLE SHOWS THE EFFECTS OF WAF CONCENTRATION, TIME OF EXPOSURE AND INTERACTION BETWEEN BOTH, AND THE PERCENTAGE OF RELATIVE CONTRIBUTION OF EACH FACTOR TO EXPLAIN EACH MODEL. ASTERISKS INDICATE * $\mathrm{p}<0.05$ AND $* * p<0.005$ FROM BONFERRONI TEST

\begin{tabular}{|c|c|c|c|c|c|c|c|}
\hline \multirow{3}{*}{$\begin{array}{l}\text { Transcripts } \\
\text { CYP1A }\end{array}$} & \multirow{5}{*}{$\begin{array}{l}\text { Factors } \\
\text { WAF } \\
\text { time } \\
\text { interaction }\end{array}$} & \multicolumn{3}{|c|}{ Liver } & \multicolumn{3}{|c|}{ Gill } \\
\hline & & \multirow{2}{*}{$\begin{array}{c}\mathrm{F} \\
29.9\end{array}$} & \multicolumn{2}{|c|}{$\begin{array}{c}\text { relative } \\
\text { contribution }\end{array}$} & $\mathrm{F}$ & \multicolumn{2}{|c|}{$\begin{array}{c}\text { relative } \\
\text { contribution }\end{array}$} \\
\hline & & & $* *$ & $71 \%$ & 35.0 & $* *$ & $33 \%$ \\
\hline & & 4.3 & & $5 \%$ & 39.7 & $* *$ & $19 \%$ \\
\hline & & 4.4 & $*$ & $10 \%$ & 44.2 & $* *$ & $42 \%$ \\
\hline \multirow[t]{3}{*}{ CYP2K1 } & WAF & 5.4 & $*$ & $10 \%$ & 5.3 & $*$ & $7 \%$ \\
\hline & time & 28.3 & $* *$ & $27 \%$ & 27.6 & $* *$ & $19 \%$ \\
\hline & interaction & 26.4 & $* *$ & $51 \%$ & 47.3 & $* *$ & $65 \%$ \\
\hline \multirow[t]{3}{*}{ CYP2M1 } & WAF & 27.0 & $* *$ & $15 \%$ & 5.4 & & $8 \%$ \\
\hline & time & 67.1 & $* *$ & $19 \%$ & 117.6 & $* *$ & $83 \%$ \\
\hline & interaction & 112.7 & $* *$ & $63 \%$ & 0.5 & & $1 \%$ \\
\hline \multirow[t]{3}{*}{ CYP3A27 } & WAF & 2.4 & & $7 \%$ & 2.3 & & $8 \%$ \\
\hline & time & 26.0 & $*$ & $33 \%$ & 32.3 & $* *$ & $59 \%$ \\
\hline & interaction & 7.9 & $*$ & $22 \%$ & 3.0 & & $11 \%$ \\
\hline
\end{tabular}


well as by endogenous substrates (Uno et al. 2012), which implies that internal metabolism should change their mRNA levels over time, maybe explaining experimental-control differences over time. In this study, CYP2K1 was induced after $24 \mathrm{~h}$ exposure to WAF, as it was previously observed in reef fish (Zhu et al.2008). In contrast, more extended time and high PAH concentration (e.g. exposed trout to $5 \% \mathrm{WAF}, 96 \mathrm{~h}$, and exposed wild trout) appears to down-regulate CYP2K1. More studies are needed to understand if down-regulation of liver CYP2K1 and CYP2M1 and gill CYP2K1 were caused by the disruption of physiologic homeostatic processes in which CYP2K1 and CYP2M1 enzymes participate (Zhu et al. 2008, Browne et al. 2010), or by alterations in the metabolism of estrogenic hormones (testosterone, progesterone, estradiol) and fatty acids, which could lead to the inhibition of CYP2K1 and CYP2M1 transcript expression, for example, by estradiol (Buhler et al. 2000, Sovadinová 2006). Although the results in the WAF experiment are not conclusive, differences among time response of CYP2 expression could be useful as complementary indicators of pollution by crude oil.

We found induced CYP3A27 transcript levels only in liver of impacted wild trout, suggesting an induction at longer time than four days. Gene expression of CYP3A27 has been reported to be regulated by pregnane $\mathrm{X}$ receptor (PXR) in rainbow trout hepatocytes (Wassmur et al. 2010). Since PAHs activate the PXR signaling pathway in humans (Luckert et al. 2013), it could be speculated that oil PAHs induce $O$. mykiss CYP3A27 expression through PXR. However, there are few studies on the nature of PXR ligands in fish (Ekins et al. 2008, Krasowski et al. 2011, Bainy et al. 2013) and their results show differences in ligand affinity between fish and mammalian PXRs, and also among fish species. Moreover, crosstalk between AhR and PXR cannot be discarded as an alternative explanation for PXR signaling activation by oil contaminants.

Thus, while CYP1A mRNA expression appears to be a more robust biomarker for detecting the effects of crude oil under different dose and exposure time, the expression of CYP2K1, CYP2M1 and CYP3 mRNAs could supply additional information such as different exposure time to oil pollution in freshwater systems. The results obtained in wild rainbow trout could be particularly useful to evaluate other freshwater pollution, since the TPH concentration varied along the stream reach and rainbow trout was not exposed to a constant concentration of the pollution for several hours, unlike the experiments. The study of mRNA expression patterns of multiple CYP genes in rainbow trout gills and liver would be extended in order to evaluate their use for monitoring programs of crude oil pollution and remediation actions on $\mathrm{Pa}$ tagonian freshwater ecosystems. As far as we know, this is the first ecotoxicological study on the oil spill in La Mina stream, and one of the few related studies in Patagonia. Since oil exploration and extraction activities are expected to be enhanced in this region in the future, further studies and monitoring programs are needed to protect the quality of valuable water ecosystems, fish production in downstream reservoirs and human health.

\section{ACKNOWLEDGMENTS}

This work was supported in part by grant 15110027 from Fondo de Financiamiento de Centros de Investigación en Áreas Prioritarias (FONDAP) of Chile and the grant ANPCYT PICT 2013-1415 of Argentina. We thank the team of the Instituto de Bioquímica y Microbiología of the Universidad Austral de Chile (Valdivia, Chile), for their kind help in the laboratory work. Also, we wish to thank Dr. Nicolás Ferreiro for field assistance and Pablo Hualde for his advice in fishing gear. We thank the staff of the hatchery of the Centro de Ecología Aplicada de Neuquén (Neuquén, Argentina) for the supply of fish, and we thank YPF Foundation for supplying information about the crude oil of La Mina stream. L.R. Leggieri has a post-doctoral fellowship from the National Research Council (CONICET-YPF).

\section{REFERENCES}

Bailey G. S., Williams D. E. and Hendricks J. D. (1996). Fish models for environmental carcinogenesis: the rainbow trout. Environ. Health Perspect. 104 (1), 5-21. DOI: $10.2307 / 3432693$

Bainy A. C., Kubota A., Goldstone J. V., Lille-Langoy R., Karchner S. I., Celander M. C., Hahn M. E., Goksøyr A. and Stegeman J. J. (2013). Functional characterization of a full length pregnane $\mathrm{X}$ receptor, expression in vivo, and identification of PXR alleles, in Zebrafish (Danio rerio). Aquat. Toxicol. 142-143, 447-457.

DOI: 10.1016/j.aquatox.2013.09.014

Barquín M., Ríos S. M. and Nudelman N. (2011). The application of toxicity test on the specie Atriplex lampa in the risk assessment of oil spills in Patagonian soils. Rev. Toxicol. 28 (2), 135-139 
Buhler D. R., Miranda C. L., Henderson M. C., Yang Y. H., Lee S. J. and Wang-Buhler J. L. (2000). Effects of 17 beta-estradiol and testosterone on hepatic mRNA/ protein levels and catalytic activities of CYP2M1, CYP2K1, and CYP3A27 in rainbow trout (Oncorhynchus mykiss). Toxicol. Appl. Pharmacol. 168 (2), 91-101. DOI: 10.1006/taap.1999.9016

Buhler D. R. and Wang-Buhler J. L. (1998). Rainbow trout cytochrome P450s: purification, molecular aspects, metabolic activity, induction and role in environmental monitoring. Comp. Biochem. Physiol. C Pharmacol. Toxicol. Endocrinol. 121 (1-3), 107-137. DOI: $10.1016 / \mathrm{S} 0742-8413(98) 10033-6$

Buhler D. R., Yang Y. H., Dreher T. W., Miranda C. L. and Wang J. L. (1994). Cloning and sequencing of the major rainbow trout constitutive cytochrome $\mathrm{P} 450$ (CYP2K1): identification of a new cytochrome P450 gene subfamily and its expression in mature rainbow trout liver and trunk kidney. Arch. Biochem. Biophys. 312 (1), 45-51.

DOI: 10.1006/abbi.1994.1278

Cazau L., Cortiñas J., Reinante S., Asensio M., Bechis F. and Apreda D. (2005). Cuenca de Nirihuau. In: Frontera Exploratoria de la Argentina, $6^{\circ}$ Congreso de Exploración y Desarrollo de Hidrocarburos, (G.A. Chebli, J. Cortiñas, L.A. Spalletti, L. Legarreta, E.L. Vallejo, Eds.), Mar del Plata, Argentina, pp. 251-273.

Chang C. C., Sue Y. M., Yang N. J., Lee Y. H. and Juan S. H. (2014). 3-Methylcholanthrene, an AhR agonist, caused cell-cycle arrest by histone deacetylation through a rhoa-dependent recruitment of HDAC1 and pRb2 to E2F1 complex. PLoS ONE 9 (3), e92793. DOI: 10.1371/journal.pone.0092793

Clark B. W., Matson C. W., Jung D. and Di Giulio R. T. (2010). AHR2 mediates cardiac teratogenesis of polycyclic aromatic hydrocarbons and PCB-126 in Atlantic killifish (Fundulus heteroclitus). Aquat. Toxicol. 99 (2), 232-240. DOI: 10.1016/j.aquatox.2010.05.004

Collier T. K., Krone C. A., Krahn M. G., Stain J. E., Chan S. L. and Varanasi U. (1996). Petroleum exposure and associated biochemical effects in subtidal fish after the Exxon Valdez oil spill. Proceedings. Exxon Valdez Oil Spill Symposium, American Fisheries Society Symposium press. Anchorage Alaska, 2-5 February 1993, pp. 671-683.

Danielson P. B. (2002). The cytochrome P450 superfamily: biochemistry, evolution and drug metabolism in humans. Curr. Drug Metab. 3 (6), 561-597. DOI: $10.2174 / 1389200023337054$

Ekins S., Reschly E. J. Hagey L. R. and Krasowski M. D. (2008). Evolution of pharmacologic specificity in the pregnane X receptor. BMC Evol. Biol. 8 (1), 103-124. DOI: $10.1186 / 1471-2148-8-103$
EPA (1978). Method 418.1: Petroleum hydrocarbons (Spectrophotometric infrared). United States Environmental Protection Agency. Manual. Washington, D.C., USA, 8 pp.

Goksøyr A. (1995). Use of cytochrome P450 1A(CYP1A) in fish as a biomarker of aquatic pollution. Arch. Toxicol. $17,80-95$.

DOI: 10.1016/0378-4274(94)90283-6

Jönsson M. E., Gao K., Olsson J. A., Goldstone J. V. and Brandt I. (2010). Induction patterns of new CYP1 genes in environmentally exposed rainbow trout. Aquat. Toxicol. 98 (4), 311-321.

DOI: 10.1016/j.aquatox.2010.03.003

Jönsson M. E., Orrego R., Woodin B. R., Goldstone J. V. and Stegeman J. J. (2007). Basal and 3,3',4,4',5-pentachlorobiphenyl-induced expression of cytochrome P450 1A, 1B and 1C genes in zebrafish. Toxicol. Appl. Pharmacol. 221 (1), 29-41.

DOI: 10.1016/j.taap.2007.02.017

Jönsson M. E., Abrahamson A., Brunstrom B. and Brandt I. (2006). Cytochrome P4501A induction in rainbow trout gills and liver following exposure to waterborne indigo, benzo[a]pyrene and 3,3',4,4',5-pentachlorobiphenyl. Aquat. Toxicol. 79 (3), 226-232.

DOI: 10.1016/j.aquatox.2006.06.006

Krasowski M. D., Ai N., Hagey L. R., Kollitz E. M., Kullman S. W., Reschly E. J. and Ekins S. (2011). The evolution of farnesoid $\mathrm{X}$, vitamin $\mathrm{D}$, and pregnane $\mathrm{X}$ receptors: insights from the green-spotted pufferfish (Tetraodon nigriviridis) and other non-mammalian species. BMC Biochem. 12 (1), 5.

DOI: $10.1186 / 1471-2091-12-5$

Lee S. J. and Buhler D. R. (2003). Cloning, tissue distribution, and functional studies of a new cytochrome P450 3A subfamily member, CYP3A45, from rainbow trout (Oncorhynchus mykiss) intestinal ceca. Arch. Biochem. Biophys. 412 (1), 77-89. DOI: 10.1016/S0003-9861(03)00029-8

Lee S. J., Hedstrom O. R., Fischer K., Wang-Buhler J. L., Sen A, Cok I. and Buhler D. R. (2001). Immunohistochemical localization and differential expression of cytochrome P450 3A27 in the gastrointestinal tract of rainbow trout.Toxicol. Appl. Pharmacol. 177 (2), 94-102. DOI: 10.1006/taap.2001.9289

Luckert C., Ehlers A., Buhrke T., Seidel A., Lampen A. and Hessel S. (2013). Polycyclic aromatic hydrocarbons stimulate human CYP3A4 promoter activity via PXR. Toxicol. Lett. 222 (2), 180-188. DOI: $10.1016 /$ j.toxlet.2013.06.243

Ma Q. and Baldwin K.T. (2002). A cycloheximidesensitive factor regulates TCDD-induced degradation of the aryl hydrocarbon receptor. Chemosphere 46 (9-10), 1491-1500. 
Mancini D. and Serna M. (1989). Evaluación petrolera de la cuenca de Nirihuau. Sudoeste de Argentina. Actas. $1^{\circ}$ Congreso Nacional de Exploración de Hidrocarburos. Mar del Plata, Argentina, 17-21 April 1989, pp. 739-762.

Meyer J. N., Wassenberg D. M., Karchner S. I., Hahn M. E. and Di Giulio R. T. (2003). Expression and inducibility of aryl hydrocarbon receptor pathway genes in wild-caught killifish (Fundulus heteroclitus) with different contaminant-exposure histories. Environ Toxicol Chem. 22 (10), 2337-2343. DOI: 10.1897/02-495

Mimura J., Emma M., Sogawa K. and Fujii-Kuriyama Y. (1999). Identification of a novel mechanism of regulation of Ah (dioxin) receptor function. Genes Dev. 13 (1), 20-25. DOI: 10.1101/gad.13.1.20

Miranda C. L., Wang J. L., Henderson M. C., Zhao X., Guengerich F. P. and Buhler D. R. (1991). Comparison of rainbow trout and mammalian cytochrome $\mathrm{P} 450$ enzymes: Evidence for structural similarity between trout P450 LMC5 and human P450111A4. Biochem. Biophys. Res. Commun. 176 (2), 558-563.

DOI: $10.1016 / \mathrm{S} 0006-291 \mathrm{X}(05) 80220-7$

Moore M., Depledge M., Readman J. and Leonard D. (2004). An integrated biomarker-based strategy for ecotoxicological evaluation of risk in environmental management. Mutat. Res. 552 (1-2), 247-268.

DOI: $10.1016 /$ j.mrfmmm.2004.06.028

Nahrgang J., Camus L., Carls M. G., González P., Goksøyr A., Christiansen J. S. and Hop H. (2009). PAH biomarker responses in polar cod (Boreogadus saida) exposed to benzo(a)pyrene. Aquat. Toxicol. 94 (4), 309-319. DOI: 10.1016/j.aquatox.2009.07.017

Parsons T. W. (2002). Pioneros olvidados: argentinos y uruguayos. Editado por TW Parsons, Bariloche, 356 pp.

Pascual M., Macchi P., Urbanski J., Marcos F., Riva Rossi C., Novara M. and Dell'Arciprete P. (2002). Evaluating potential effects of exotic freshwater fish from incomplete species presence-absence data. Biol. Invasions 4 (1-2), 101-113. DOI: 10.1023/A:1020513525528

Quirós R. (1990). Predictors of relative fish biomass in lakes and reservoirs of Argentina. Can. J. Fish. Aquat. Sci. 47 (5), 928-939. DOI: 10.1139/f90-107

SAyDS (2000). Segundo informe nacional para la implementación de la Convención de las Naciones Unidas de lucha contra la desertificación. Secretaría de Ambiente y Desarrollo Sustentable, Dirección de Conservación de suelos. Informe, Buenos Aires, Argentina, 64 pp.

Singer M. M., Aurand D., Bragin G. E., Clark J. R., Coelho G. M., Sowby M. L. and Tjeerdema R. S. (2000).
Standardization of the preparation and quantitation of water-accommodated fractions of petroleum for toxicity testing. Mar. Pollut. Bull. 40 (11), 1007-1016. DOI: $10.1016 / \mathrm{S} 0025-326 \mathrm{X}(00) 00045-\mathrm{X}$

Sovadinová I. (2006). Nuclear receptor-mediated toxicity of xenobiotics. Doctoral Thesis. Masaryk University, Czech Republic, 62 pp.

Thomas R. E. and Rice S. D. (1981). Excretion of aromatic hydrocarbons and their metabolites by freshwater and seawater Dolly Varden char. In: Biological monitoring of marine pollutants (F.J. Vernberg, A. Calabrese, F.P. Thurberg, W.B. Venberg, Eds.). Academic Press, New York, USA, pp. 425-448.

Uno T., Ishizuka M. and Itakura T. (2012). Cytochrome P450 (CYP) in fish. Environ. Toxicol. Pharmacol. 34 (1), 1-13. DOI: 10.1016/j.etap.2012.02.004

Varanasi U. (1989). Metabolism of polycyclic aromatic hydrocarbons in the aquatic environment. CRC, Boca Raton, F.L., USA,341 pp.

Wassmur B., Gräns J., Kling P. and Celander M. C. (2010). Interactions of pharmaceuticals and other xenobiotics on hepatic pregnane X receptor and cytochrome $\mathrm{P} 450$ 3 A signaling pathway in rainbow trout (Oncorhynchus mykiss). Aquat. Toxicol. 100 (1), 91-100.

DOI: $10.1016 /$ j.aquatox.2010.07.013

Yang Y. H., Miranda C. L., Henderson M. C., Wang-Buhler J. L. and Buhler D. R. (2000). Heterologous expression of CYP2K1 and identification of the expressed protein (BV-CYP2K1) as lauric acid (omega-1)-hydroxylase and aflatoxin B1 exo-epoxidase. Drug Metab. Dispos. 28 (11), 1279-1283.

Yang Y. H., Wang J. L., Miranda C. L. and Buhler D. R. (1998). CYP2M1: cloning, sequencing, and expression of a new cytochrome P450 from rainbow trout liver with fatty acid (omega-6)-hydroxylation activity. Arch. Biochem. Biophys. 352 (2), 271-280.

DOI: 10.1006/abbi.1998.0607

Zanette J., Jenny M. J., Goldstone J. V., Woodin B. R., Watka L. A., Bainy A. C. and Stegeman J. J. (2009). New cytochrome P450 1B1, 1C2 and 1D1 genes in the killifish Fundulus heteroclitus: basal expression and response of five killifish CYP1s to the AHR agonist PCB126. Aquat. Toxicol. 93 (4), 234-243.

DOI: $10.1016 /$ j.aquatox.2009.05.008

Zhu S., King S. C. and Haasch M. L. (2008). Biomarker induction in tropical fish species on the northwest shelf of Australia by produced formation water. Mar. Environ. Res. 65 (4), 315-324.

DOI: 10.1016/j.marenvres.2007.11.007 